\title{
The politics of literary translation
}

\section{Francis R. Jones, Newcastle University, England, UK}

\section{INTRODUCTION}

Palić Lakeside, Northern Serbia, a summer evening in 1987. Serbia is still a component republika of Communist-led Yugoslavia. I'm watching an open-air version of Shakespeare's Julius Caesar - not in Serbo-Croat, Yugoslavia's main language, but in Hungarian, this region's biggest minority language. The play starts. An open-top Mercedes crunches across the gravel between two waterside lodges, bearing Caesar, clad in cream-coloured suit, every inch the modern Communist-Party bigwig. In the final, civil-war scene, Brutus's and Cassius's forces are in one lodge, and Antony's and Octavian's in the other - wearing uniforms and bearing weapons that the director has somehow borrowed from the local Territorial Defence forces. The climax is a deafening ten-minute firefight, the darkness lit by flares and the muzzle-flashes of Kalashnikovs. Had this staging been attempted in Belgrade, Yugoslavia's capital, and in Serbo-Croat, the Party bosses would have quickly closed down this parable of power about them. With a minority-language audience in a small border town, they could look the other way - but giving subversive messages to big, capital-city audiences would be another thing. (Five years later, as Yugoslavia bloodily broke apart, the Communist-Party bosses had morphed into nationalist warlords, and had instigated a real civil war - unlike in the play, fought with live ammunition.)

Literary translation, therefore, can be political. Because literature engages with the world, it can also engage with politics - and translating literature makes this engagement international. I experienced this during the 1990s as a literary translator from Serbo-Croat (which became relabelled 'Bosnian', 'Croatian' and 'Serbian' as Yugoslavia's republike 
became independent states). With ethno-nationalist politics (based on loyalty to an ethnic group: Miščević 2014) driving Yugoslavia’s break-up in a chain of brutal wars and humanrights violations, I was constantly aware of taking a political stance. Some of this chapter's examples derive from my experience: for transparency's sake, these are identified as such.

First, however, it is worth defining some key concepts as used in this chapter. Politics is seen as comprising 'that which concerns the state', its institutions and people (Czajka 2016: 14) - how far Yugoslav Communist-Party officials could be criticised, for instance. It also encompasses how communities create and engage with the rules of public life, and structures of social power $(18,20-1)$ - feminist resistance to male-led power-systems, for example.

Political views and actions are often driven by ideologies: sets 'of ideas, values and beliefs that govern a community' because they appear 'commonsensical' (Calzada Pérez 2003: 5; Verschueren 2012: 10). Examples are 'ethno-nationalism', and 'civic nationalism' (loyalty to a state or part of a state: Miščević 2014). 'Ideology' is not necessarily pejorative: thus 'cosmopolitanism' (seeing all people as 'citizens in a single community': Kleingeld and Brown 2013) and 'pernicious' ethno-nationalism (claiming rights for one's own ethnic community whilst denying them to other communities: Miščević 2014) are both ideologies in this sense.

This chapter focuses on interlingual translation (Jakobson [1959] 2000: 114), where texts are transmitted in roughly similar form across languages. 'Intralingual' adaptations within one language may also be politicised, however. In an Italian Fascist-era variation on Carlo Collodi's 1883 novel Le avventure di Pinocchio [The Adventures of Pinocchio], for instance, Pinocchio becomes an imperialist adventurer during Mussolini’s land-grab in 1930s Africa (Sinibaldi 2011: 349-50). The same holds for interlingual adaptations or inspirations, as with German poet Barbara Köhler's Niemands Frau [Nobody's wife/woman], which gives voice to the marginalised female characters in Homer's Odyssey (R. M. Johnson 2016). 
Translation, of course, involves more people than just the translator. Translations are produced and published by 'teams' of 'actors': an editor, poets, and translators - me included - producing an English-language journal edition of Serbian women's poetry, for instance (Pro Femina: Slapšak 1997a). Teams engage with larger 'interest communities': readers interested in women's poetry, say. They may also oppose interest communities: Slapšak’s collection aimed to resist 1990s Serbia's 'male/national[ist]/patriarchal conglomerate' (Slapšak 1997b: 11), for example.

Literature (as discussed in Jones 2009: 52) is seen as a 'super-genre' encompassing various component genres - drama or poetry, for example. A genre's writers and readers share expectations about their genre's typical language forms and communicative purpose. In language-form terms, literary texts are usually written - even if also spoken, like drama. They may use 'poetic' language (where the form of language is important, like wordplay or rhyme: Jakobson [1960] 1988: 37), ambiguity, and multiple voices. They may also use 'minoritized' (non-mainstream) styles like dialect, slang or archaism. The communicative purpose of literary texts is usually to entertain, or to give emotive or aesthetic experiences. They also have high social value. But whether they tell the truth about the world (about Julius Caesar's death, say) is irrelevant. Other genres share some of these features: advertising uses 'poetic' language, for instance. But the more features a text has, the likelier its users are to see it as literary. Thus some component genres - like poetry, drama and prose fiction - are seen as archetypally literary because they have many such features. Component genres also have their own features: live spoken dialogue in drama, for example. 


\section{CONVEYING POLITICAL MESSAGES}

Literary translations can convey political messages in three key ways: which texts are chosen for translation, how the translator translates, and how they are presented to readers. These are explored further in this section.

Firstly, some literary source texts have political content. Because literary translations are usually presented as the work of a named source writer (unlike advertising or law translations, for instance), loyalty to the source writer is an important norm, or working ethic, in literary translation. This means aiming to communicate source-text content reliably, unless the translator or another team member (e.g. a play director) consciously decides to adapt. Hence choosing to translate a literary text with political content almost always also communicates that content. Teams, however, may highlight the content's relevance to target audiences - for instance, by updating an older text, as the Julius Caesar example shows. Furthermore, non-literary political texts may use literary quotes to strengthen their message. For example, a book which I co-translated (Mahmutćehajić [1994] 1996) was prefaced with a poem about the resilience of medieval Bosnian heretics in the face of persecution. This introduced the book's purpose: to defend a cosmopolitanist model of Bosnian society, which was then under threat from ethno-nationalist rebel armies. This function also normally remains when such texts are translated.

Most literary translations, however, actually have a double aim: not just to report on source-text content, but also to act as literary texts in their own right - as target-language poems, for instance. But literal equivalents are often stylistically clumsy, and literature's rich use of linguistic effects (like wordplay) and cultural content can make it hard to translate literally anyway. Hence literary translators often translate non-literally, which gives variations between different translators' wordings. These can also reveal the politics of translators, teams, and their communities (Tymoczko 2014: 16-21). By translating some 
sentences faithfully and euphemising or omitting others, for example, a female Taiwanese translator kept the feminist messages of US novelist Alice Walker's The Color Purple while downplaying its anti-colonial messages, but a male translator did the reverse (T.-Y. Lee 2010). These changes typically either soften or heighten political messages already in the source text, as Lee's study shows: only rarely do they introduce new political messages (Jones 2016).

Such politically-driven textual changes may happen without the translator being aware of their political motivation. The political motivation sometimes appears more conscious, however - especially in drama, which has a tradition of updating classic plays to show their modern relevance. In Aeschylus's Agamemnon (458 BCE), for instance, the chorus laments how ordinary people suffer when their rulers wage war. Tony Harrison's early-1980s translation stressed the universality of this lament by introducing references to the modern US army ('dogtags') and the bloody 1980s Iran-Iraq war ('battle-martyr') alongside original Ancient-Greek references ('amphorae'): 'wives mothers sisters each one scans / the dogtags on the amphorae / which grey ashes are my man's? / they sift the jumbled ashes and cry: / my husband sacrificed his life / my brother's a battle-martyr' (Aeschylus [458 BCE] 1986: 201).

Alternatively, the motivation for publishing translated literature may be political, whatever the texts' content. Publishing teams used poetry translations from Bosnian during the 1990s war, for instance, to combat Western stereotypes of Bosnia as a hotbed of warring tribes where it would be foolish to intervene, promoting it instead as a single, culturallysophisticated European region that deserved international protection (Jones and Arsenijević 2005). The political motivation is then often stated in 'paratexts': elements, like introductions or cover blurbs, that accompany the literary text. For instance, the introduction to a Turkish translation of Daniel Defoe's Robinson Crusoe presented the novel as 
imperialist and anti-Islamic (Kansu-Yetkiner 2014: 345-8). Or the motivation may be implied by where the translation is published, or by its targeted readers. Thus, when my English translation of Hasanaginica, an eighteenth-century epic poem about a tragic divorce in a Bosnian Muslim community, appeared in the Sarajevo-based academic journal Forum Bosnae (Anonymous [1774] 2010), I saw it as helping the journal's cosmopolitanist aim of promoting religious and cultural diversity as a strength of Yugoslavia's successor states. But a Serbian contributor posted another translation of this poem, on the far-right web forum Stormfront (delfinella 2007), for the opposite purpose. This was to promote the greatness of Serbian culture to other ethnic supremacists, within a pernicious ethno-nationalist model of Serbian identity. (Allegiance to Orthodox Christianity and opposition to Islam is central to this model, however. Hence it is interesting that delfinella chose to promote it with Hasanaginica, which assumes traditional Islamic views of marriage and family.)

Literary translation bridges cultures, the cliché has it. But cultures carry different amounts of power: hence the act of bridging may itself be political. Some literatures and languages are globally powerful ('dominating': Casanova [2002] 2010; cf. Venuti 1995): often read by non-native users and often translated, but importing relatively little translated literature. Most, however, are 'dominated' (Casanova [2002] 2010): read by few non-native users and rarely translated, but importing a lot of translated literature. To gain international recognition, dominated literatures often depend on translation into 'vehicular' globalised languages (Apter 2001: 65) - typically, dominating ones. If writers in such literatures (Japan’s Haruki Murakami, for example) succeed in being translated, especially into a dominating language, they become 'consecrated' - that is, gain prestige - within their own literary culture (Casanova [2002] 2010). This gives translation teams cultural power, because they decide who becomes consecrated by translation, and who does not. Venuti (1995: 18-24) argues that a dominating target literary culture, like US English, imposes its own 
'domesticating' norms, determining what sort of works are selected for translation, and how they are translated - with US publishers allegedly preferring a bland 'fluency', whatever the source text's style.

Such views highlight global inequalities, but have also been accused of perpetuating them, because they take the dominance of certain Western languages as given (Beecroft 2008, in Baker 2010: 320). Moreover, a crucial factor in the purpose and effects of global literarytranslation flows is the geographic 'positionality' of the translating team - where key members are based, and whether the team subscribes to target- or source-country values. Venuti's model assumes that literary translation is controlled by teams based in a globallydominant target country whose values they share. Many dominated-to-dominating translation teams, however, are actually led by source-culture actors, who wish to promote their own source culture's or community’s values (Serbian editor Svetlana Slapšak, for instance: 1997a). Teams may, however, include target-language natives who share these priorities like Slapšak's translators. Such teams use the globalised target language to gain an international audience for their own choice of source works, translated for source-culture purposes and in a style that the team chooses (Jones 2010: 246-7). This can enrich the dominating language. Thus bringing 'Korean linguistic experience into English' via poetry translation can make English 'expand to incorporate new works, rhythms, associations, and thereby new political possibilities' (Dugdale 2017: 3, citing Choi).

\section{WHAT POLITICS IS PROMOTED?}

The politics highlighted by literary translations may be state-based, as with the translations above that defend statehood or assert nation-state identity. Or based around colonial or postcolonial relations between nations or states, as when nineteenth-century translators sought to 
strengthen Irish identity and resist English colonialism by translating Irish classics into the coloniser's language (Tymoczko 1999: 21).

Alternatively, the politics may focus on power relationships within states - ethnicity and social status, for example. Thus, in US novelist William Faulkner's The Sound and the Fury, the different social status of African-American and poor-white characters is marked by differences in dialect: this socio-political message is lost if both groups speak the same dialect in translation (Määttä 2004: 322-32).

By highlighting or ignoring regional language-use, literary translation can engage with the politics of regional identity or regional nationalism. For example, twentieth-century literary translations - like Brian Holton's translations from the classic Chinese outlaw novel 水湤传(Shui Hu Zhuan) - were crucial in re-establishing Scots as a literary language (Findlay 2004), thus raising its status as a marker of Scottish civic-nationalist identity. Similarly, translating Shakespeare into vernacular (popular spoken) Québec French asserts the autonomy of Québec both in Canada, where English speakers predominate, and in the French-speaking world (Lieblein 2004). Moreover, vernacular and regional language can subvert the dominance of the standard language, and of its users, who are almost always socially powerful: 'standing up for the small tongues against the big mouths', in poet and translator William Neill's words (Scottish Poetry Library 2012). Hence some scholars see it as crucial to retain such language in translation, especially because translating into standard language reasserts the dominance of the socially powerful. However, finding an equivalent target-language variety can be difficult. There is no obvious variety of French, for instance, which gives similar social signals as Faulkner's use of 1930s African American Vernacular (Määttä 2004: 322; cf. Duranti 1989; Weston 2006).

Similarly, it is often crucial but not always easy to retain gender-political messages in translation. The feminist subtleties of Anglophone Canadian writer Margaret Atwood's 
poems can be hard to retain in Spanish, for instance, because Spanish is more grammatically gendered than English: adjectives cannot stay gender-neutral, but must be masculine or feminine (Somacarrera 2005).

Religion is intertwined with politics. Religion may be a marker of identity for communities in a political relationship - Bosniaks (Bosnian Moslems) and Serbs (Orthodox Christians) in the Balkans, for instance. And translated literature may engage with this relationship, as shown above. Religions also set rules of public life for their followers, which may intersect with other public values via translation. In 1991, Hitoshi Igarashi, Islamicstudies academic and Japanese translator of Salman Rushdie's novel The Satanic Verses, was found stabbed to death outside his office. Though no-one was charged with his murder, in 1989 Iran's Ayatollah Khomeini had called on Muslims to kill Rushdie because The Satanic Verses was allegedly 'against Islam'. The translation's publisher had also received death threats from Islamic militants; and the novel's Norwegian publisher, Italian translator and Turkish translator survived assassination attempts. This clash of ideologies - respect for religious belief versus freedom of literary expression - was both public and had a power dimension, and can therefore be seen as political.

Literary translation may also promote images of the source culture for political ends: promoting Ireland's Celtic literary heritage to help justify the nineteenth-century independence movement, as mentioned earlier. And different interest communities may have different ends. As mentioned above, cosmopolitanist communities used translations of Bosnian literature to argue for international support for Bosnia as a unitary, multi-cultural state during the 1990s war. Bosnian-Serb ethno-nationalist warlord Radovan Karadžić, however, used literary translation for the opposite purpose in that war. To justify his aim of partitioning Bosnia along ethno-religious lines, international peace negotiators were given 
English translations of an Ivo Andrić short story which presented Bosnia's Moslem, Catholic and Orthodox-Christian heritages as incompatible (Lovrenović 2002: 309-12).

Images of the source culture promoted by literary-translation teams may engage with target readers' stereotypes about that culture, thus participating in the political power-play between cultures mentioned above. Lee, for example, accuses Chinese-to-English translation teams of disproportionately selecting banned or subversive books for translation, and highlighting their subversiveness in paratexts (2015). This, he feels, exploits stereotypes of China as a 'repressive, dystopic Other' (251) in order to increase sales. Selecting texts for translation that fit stereotypes about the source culture, country or region is not restricted to Chinese-English translation. It can, however, go on to reinforce readers' and publishers' stereotypes - about not only the source culture, but also its literature. This makes it increasingly hard for works that do not fit such stereotypes - pro-Communist or apolitical Chinese novels, say - to be translated and published.

Translation teams, however, may also actively challenge such stereotypes. In the 1930s, for instance, Mexican diplomat José María González de Mendoza revised a French translation of Mariano Azuela's novel Mala yerba to replace images of Mexico as 'barbarous', which dated from the 1910 revolution, with more positive images (Gómez Morán 2010). And once a target-culture audience is established for a foreign literature, readers may arguably be open to exploring works that go beyond their preconceptions. Whether a team's key players - especially editors and publishers - are based in the target or source country can arguably make them more likely to follow or challenge such stereotyping respectively, as implied earlier. This is not always the case, however. In the example above, source-country actor Karadžić used a translated novel to exploit a stereotype by outsiders about his region ('Balkans as warring tribes') for his own interest community's political ends. 


\section{RELATIONSHIP WITH STATE POWER}

Literary translation can have various relationships with state political power. Firstly, states may seek to promote or reinforce their power by supporting literary translation. Intended audiences may be foreign, as when Catherine the Great's government used translations of Russian literature into French to promote eighteenth-century Russia as 'one of Europe’s enlightened courts' (Offord and Rjeoutski 2013: 1). Or domestic: Sugars, for instance, argues that translating French-Canadian novels into English aims to bolster Canadian unity by helping ‘decode’ Québec and its society for Anglophone Canadians (1996).

Secondly, literary translation may be challenge state political power. In Alexandru Tocilescu's 1985 Romanian production of Shakespeare's Hamlet, for instance, King Claudius and Queen Gertrude were cast and acted to satirise Nicolae and Elena Ceaușescu, Romania's dictatorial ruling couple (portraying Claudius as a 'vulgar and aggressive tyrant, [...] short and insignificant': Matei-Chesnoiu 2006: 207-8).

Conversely, state power may challenge literary translation, by banning or censoring incoming and/or outgoing translations, or by censoring translators' paratexts (Tan 2015: 316). Censors may demand that text be deleted or changed before or after publication; alternatively, translators or publishers may self-censor their texts (316). Source writers may even censor their texts before translation - like Václav Havel in Communist Czechoslovakia (Woods 2012, in Toth 2015: 844). Censorship may vary by genre. During dictator Francisco Franco's regime, for instance, 1960s-1970s Spanish censors focused less on poetry, because it had smaller print runs, than on prose (Lobejón Santos 2015: 54). Conversely, censorship can influence genre conventions. In Franco's Spain, foreign-language films were dubbed rather than subtitled, for instance, so that audiences could not compare the censored target dialogue with the source - in the 1942 US film Casablanca, say, deleting references to hero Rick 
having fought on the anti-Francoist Republican side in the Spanish Civil War (Mira 2010). Both political content proper and moral content may be censored (Tan 2015: 316; Lobejón Santos 2015: 55-57). The latter may be seen as political, however, if it involves power relationships between interest communities, or if it is exploited directly by politicians. Thus the enlistment of conservative Catholic values into Franco's Fascist ideology meant that his censors also monitored sexual content (Lobejón Santos 2015: 55-57). In the 1952 US film Mogambo, for instance, they turned adulterous lovers into brother and sister - which made the lovers' passionate on-screen kiss late in the film unsettling, to say the least (Aranda 2007: $32)$.

\section{TRANSLATION, POLITICS AND HISTORY}

Literature has been translated for millennia, and literary translation's potential links with politics have lasted just as long. Hence a systematic historical overview is beyond the scope of this chapter. This section, therefore, looks just at the nineteenth and twentieth centuries, focusing on two of their key geo-political phenomena: global imperialism, and the Cold War. A third phenomenon, the twentieth-century European dictatorships, is mentioned above with examples from Mussolini's Italy, Franco's Spain and Ceaușescu's Romania, so will not be examined further.

Empire-building by European countries involved establishing ideologies of cultural superiority to justify political control. Literary translation often supported this. The Arabic folk-tale collection Thousand and One Nights, for example, was so widely translated into nineteenth-century Europe that it became seen as emblematic of Arabic literature.

Characterising a rich and varied literature through one folky, picturesque work, however, arguably supported the 'orientalist' view that Middle-Eastern societies were less evolved than European ones (Shamma 2005) - thus giving an intellectual justification for European 
colonialism. With Burton's 1885 English version, Shamma argues, this folksiness is supported by a supposedly 'literal' translation style that is actually 'eccentricizing' and 'exoticizing' (63).

Resistance to empire involved subverting such claims to cultural superiority - again with literary translation as a key tool. Translating Irish-language classics to validate Irish culture in resistance to British colonialism, for example, is mentioned above. Alternatively, resistance involved hijacking the coloniser's culture. In nineteenth-century China, for instance, intellectuals and officials encouraged the translation of Western works into Chinese, so that, armed with up-to-date knowledge, China could better resist the encroaching European colonisers. Political, philosophical, scientific and military works were translated. But also literature, because it often contained progressive ideas while being enjoyable to read, which enabled the ideas to reach a wider audience (Lung 2004: 161-2).

The wish to publicise progressive ideas underlay a good number of nineteenth-century literary translations in non-colonial contexts too. Thus the 1853 Romanian translation of Harriet Beecher Stowe's US anti-slavery novel Uncle Tom's Cabin gave crucial support for abolishing Roma slavery in the territories that would later form Romania (Mihăilă 2005).

Both opposition to and support for a foreign country’s political system may spark an interest in its literature, thus boosting translation. This was shown by Western governments' and readers' attitudes towards Latin America and Central/Eastern Europe during the Cold War. Regarding Latin America, Cohn (2006) describes a government-led policy in 1960s1970s USA to subsidise incoming literary translations, often via philanthropic bodies. There were few restrictions on political content of the works: by being seen to support freedom of expression, US policy was meant to compare favourably with the restrictions on artistic freedom imposed by many communist states. But this had the effect of promoting not just anti-communist, but also pro-communist, pro-revolutionary literature - in the latter case, 
especially with translations from revolutionary Cuba and other South American countries. This, however, enabled translated literature to reach both anti-communist and left-wing US audiences.

From the 1950s till the 1970s, there was also strong interest among Western audiences in translated literature - especially poetry - from communist Central and Eastern Europe. A key element inspiring this interest was the stereotype of 'Eastern European' writers as political actors - as witnesses to the horrors of Nazism and the Second World War, as 'heroic oppositional writer[s]' under totalitarian regimes, or simply as writers with a strong sense of their public political role (Sampson 2001: 83; Hughes and Weissbort 1965: 1). In some commentators' eyes, the need for political caution under repressive regimes meant the 'deliberate withholding' of real-world reference by poets, giving their work great metaphoric force (Szirtes 2007, in Clegg 2014: 15). More generally, source poets' political engagement was seen as altering Western 'conceptions of the poet's public role', as in UK poet Ken Smith’s work (Clegg 2014: 20). Similarly, Czesław Miłosz’s 1965 anthology of Polish poetry was seen as giving US poets 'a model of political engagement' (Rosenthal 2011: 222).

Others, however, objected to this stereotype. The label 'Eastern European' covered a vast range of literary traditions, writers, and literary themes - many of them non-political. Moreover, as Miłosz later commented (1988):

\footnotetext{
Perhaps some Western writers are longing for subjects provided by spasms of violent historical change, but $[\ldots]$ we, i.e., natives of hazy Eastern regions, perceive History as a curse and prefer to restore to literature its autonomy, dignity and independence from social pressures.
}

\section{CURRENT ISSUES AND DEBATES}

Certain issues and debates keep recurring in recent scholarship about literary translation and politics. Others occur less often, but arguably also deserve attention. 
One often-debated question is the role of literary translation in the 'dominateddominating' imbalance in global cultural power outlined above. How far does literary translation uphold such imbalances - with the huge amount of literature translated from English upholding English's dominant status, for example? Versus how far does it contest such imbalances - with translation flows that do not involve major European languages, say?

A parallel set of debates concerns the political action of literary translators. How far do they uphold existing power-systems, as with the orientalist translations mentioned above? Versus how far can or should they critique such power-systems, acting as 'ethical agent[s] of social change' (Tymoczko 2003: 181)? Venuti, writing about literary translation into US English, advocates an 'ethical politics of difference', where translators re-energise a target public's cultural and geo-political awareness by introducing foreign, different literary forms and ideas (2000: 469; 1995). For Venuti, this comes about through 'foreignizing' translations, which faithfully represent the difference between target-country literature and foreign literature, whether in terms of what works are produced or of their repertoire of literary styles. But not, as mentioned above, through 'domesticating' translations, which follow targetculture norms of text selection and target-text style. These, Venuti argues, reinforce the notion among target readers that target-culture literary norms are absolute - in the case of US English, strengthening its global cultural hegemony.

Though few would contest Venuti's views on text selection, some scholars see his views on style as simplistic. Shamma (2005: 62-6), for example, argues that a faithful, foreignizing style can work as Venuti claims when source and target cultures have equal global status. But when translating from a dominated to a dominant culture, as with Burton's Arabian Nights (see above), faithfully replicating a quirky source-text style risks reinforcing negative, us-versus-them stereotypes about the source culture. 
Scholarship on literary translation and politics is often informed by what might be called the textual manipulation hypothesis (cf. Gentzler and Tymoczko 2002: xiii). This holds that translation allows 'repressed meanings [to] resurface': that is, how translators translate a text reveals their ideologies, beliefs and attitudes, which can often reinforce existing power-systems (Gentzler 2002: 196; cf. Álvarez and Vidal 1996). To counter this, some advocate counter-manipulation by 'dissident' translation strategies, like Venuti's nonfluency, or intervention in textual content by feminist translators (Gentzler: 201-4). Gentzler himself advocates translation strategies which reveal the source text's specific contents, backed up where necessary by the translator's explanation in introductions and notes (20911).

The hypothesis itself is rarely questioned. Gentzler's favoured approach, however, implies a counter-pull against the textual-manipulation risk: the ethic, subscribed to by professional translators in all genres, of 'convey[ing] the meaning between people and cultures faithfully, accurately and impartially' (Code of Professional Conduct, ITI 2013; Jones 2016: 64-6). This implies that textual manipulation - even unconscious, and even in ideologically sensitive settings - is actually far from inevitable. A survey of Serbian-toEnglish poetry translations published during the highly politically-charged period of Yugoslavia's break-up (1992-2004) confirmed this: textual manipulation occurred in only $8 \%$ of translated poems sampled (Jones 2016: 71). Nearly all these translations combined two features. The source poems had political content, giving a catalyst for ideologised manipulation. Plus rhyme and formal rhythm which the translators tried to reproduce, which meant abandoning the effort to be semantically literal.

Textual manipulation, therefore, needs special conditions to occur. A similar combination of political content plus unreproducible style, Lane-Mercier argues, could mean that regional or socially-marked language is also sensitive to manipulation by translators 
(1997). Such language often expresses its writer's sociopolitical viewpoint (portraying dialect-users as uneducated, for example). And when it is translated, there is rarely an obvious target-language equivalent: what is the Chinese equivalent of Emily Brontë's Yorkshire dialect, for instance? Hence the target-language variety chosen also risks reflecting the translator's sociopolitical viewpoint.

If translators have strong views about the political content of the work they are translating, they can experience the conflicting pulls of textual manipulation versus professional faithfulness as a personal dilemma. I found this when translating Serbian and Bosnian poetry during the Serbian paramilitary onslaught on the Bosnian state in the 1990s (Jones 2004). The only ethical stance in such cases, Lane-Mercier argues, is for translators to take explicit responsibility for their choices, rather than presenting them as 'objective' (1997: $64)$.

\section{FUTURE AND POTENTIAL TRAJECTORIES}

The future trajectory of literary translation studies is hard to predict. Nevertheless, one currently under-researched area will almost certainly become more important. This is the potentially huge impact of new technologies on literary publishing - especially web publication. Publishing poems on web fora and in web journals, for example, is very common. And because they can potentially attract many more browsing readers than paper journals, say, web publications have strong potential to engage with and project political ideas, in the ways discussed in this chapter.

Other areas deserve more research attention, though whether they will do is less certain. One is the role of ethics in literary translation and politics - how should the translator navigate the potentially competing pulls of translating for what they see as justice versus giving voice to the source writer, for instance? Here literary translation could use 
methods and insights from fields such as community interpreting, where such issues are more thoroughly debated.

\section{RESEARCH METHODS}

Much research into literary translation and politics is based on case studies (for overviews of case-study methods, see Simons 2009 and Yin 2014). These often involve close textual comparison of one source text with one or more target texts, or analysing a historical or sociopolitical context in which translations were produced (e.g. Määttä 2004; Somacarrera 2005). Analysis is typically qualitative. The researcher scans the texts, historical archive data, etc. to establish hypotheses, uses close analysis of examples to examine the hypotheses, and then constructs a coherent argument built around these examples. This can give rich, indepth insights. Interpretation, however, can be subjective: different researchers might interpret the same data differently. And open to confirmation bias: evidence that upholds hypotheses risks being favoured, and evidence that questions them risks being ignored. Introspective studies, however, where translators report on their own translation decisions, can reduce these risks, though the reports are inevitably selective. And if the same phenomenon (textual manipulation, for instance) occurs in several different case studies, one can be more sure that this is something that really occurs, and in more than one setting.

To establish how common a phenomenon is, a quantitative - counting-based approach is needed. Within a case study, texts can be scanned systematically for features that can be quantified. For example, a 'Critical Discourse Analysis' approach may be used to log, count and analyse ideologically-motivated words or expressions within one or two target texts. And large-scale surveys of literary translations - typically of one genre, into or from one country, and in a certain time-frame - can enable hypotheses to be tested across multiple cases. 
Another way of getting the broader view of translation is to couple comparative source-target text analyses with analysing paratexts like translator's introductions, covers, etc. If this covers multiple works, this can generate powerful insights (e.g. Johnson's survey of all English translations of Pablo Neruda's political epic poem Canto General: 2010). Reader-response studies can add information on how translations are actually perceived by readers. And network-based studies look at how literary translation teams operate, often with wider interest communities (source writers or other literary translators, say). These can indicate wider patterns - for example, the political images that source-culture teams project of their society.

Some methods, however, deserve to be used more. Think-aloud studies, for example, where translators give a running commentary on their translating processes while they translate, have been widely used to examine how translator make textual decisions (Jääskeläinen 2011). To my knowledge, however, no think-aloud studies have examined the interface of literary translation and politics - whereas they could shed valuable light into why some translators change text for political reasons, for instance, and why others do not. Interviewing translators and other translation-team actors about their decisions is another method that could be used more in researching literary translation and politics. This could yield interesting insights - especially if combined with other research methods like thinkalouds.

Multiple research methods, in fact, invariably give more powerful insights than one method in isolation. Though not used to research literary translation and politics as often as they deserve, they have great potential to expand knowledge in this field. 


\section{LIST OF RELATED TOPICS IN THIS VOLUME}

Translation and Fascism, Translation and globalization, Translation and cosmopolitanism, Translation and censorship, Translation and colonialism, Translation and Feminism, Translation and national identity, Translation and the Cold War.

\section{REFERENCES}

Aeschylus ([458 BCE] 1986) 'The Oresteia', in T. Harrison, Theatre Works 1973-1985, Harmondsworth: Penguin, 185-292.

Álvarez, R. and M. C.-Á. Vidal (1996) 'Translating: A Political Act', in R. Álvarez and M. C.-Á. Vidal (eds) Translation, Power, Subversion, Clevedon: Multilingual Matters, 1-9. Anonymous ([1774] 2010) 'The Sad Song of the Noble Lady Hasan Aginica', Forum Bosnae 51: $270-5$.

Apter, E. (2001) 'Balkan Babel: Translation Zones, Military Zones', Public Culture 13(1): 65-80.

Aranda, L. V. (2007) Handbook of Spanish-English Translation, Lanham, MD: University Press of America.

Baker, M. (2010) 'Samah Selim: Editor's Introduction', in M. Baker (ed.) Critical Readings in Translation Studies, London: Routledge, 319-20.

Calzada Pérez, M. (2003) 'Introduction', in M. Calzada Pérez (ed.) Apropos of Ideology: Translation Studies on Ideology - Ideologies in Translation Studies, Manchester: St. Jerome, 1-22.

Casanova, P. ([2002] 2010) 'Consecration and Accumulation of Literary Capital: Translation as Unequal Exchange', tr. S. Brownlie, in M. Baker (ed.) Critical Readings in Translation Studies, London: Routledge, 285-303. 
Clegg, J. R. (2014) The Eastern European Context of Poetry in English after 1950, PhD thesis, Durham University.

Cohn, D. N. (2006) ‘A Tale of Two Translation Programs: Politics, the Market, and Rockefeller Funding for Latin American Literature in the United States during the 1960s and 1970s', Latin American Research Review 41(2): 139-64.

Czajka, A. (2016) What Is Politics?, Milton Keynes: Open University. delfinella (2007) Serbian Epic Poetry \#32, on website Stormfront. Available online: https://www.stormfront.org/forum/t103123-4/\#post4217233 [last access 23 July 2017]. Dugdale, S. (2017) 'Editorial', Modern Poetry in Translation 2017(1): 1-3.

Duranti, R. (1989) 'The Paradox of Distance: Belli Translated into English and Scots', New Comparison 8(Autumn): 36-44.

Findlay, B. (2004) 'Editor's Introduction', in B. Findlay (ed.) Frae Ither Tongues: Essays on Modern Translation into Scots, Clevedon: Multilingual Matters, 1-12.

Gentzler, E. (2002) 'Translation, Poststructuralism and Power', in M. Tymoczko and E. Gentzler (eds) Translation and Power, Amherst \& Boston, MA: University of Massachusetts Press, 195-218.

Gentzler, E. and M. Tymoczko (2002) 'Introduction', in M. Tymoczko and E. Gentzler (eds) Translation and Power, Amherst \& Boston, MA: University of Massachusetts Press, xi-xxviii.

Gómez Morán, J. (2010) ‘Una Revisión Documental De La Traducción Al Francés De Mala Yerba: La Intervención Del Abate González De Mendoza', Literatura Mexicana 21(2): $135-50$.

Hughes, T. and D. Weissbort (eds) (1965) Modern Poetry in Translation 1.

ITI (2013) Code of Professional Conduct. Available online: http://www.iti.org.uk/become-amember/code-of-professional-conduct [last access 1 September 2017]. 
Jääskeläinen, R. (2011) 'Studying the Translation Process', in K. Malmkjær and K. Windle (eds) The Oxford Handbook of Translation Studies, Oxford: Oxford University Press, 123-35.

Jakobson, R. ([1959] 2000) 'On Linguistic Aspects of Translation', in L. Venuti (ed.) The Translation Studies Reader, London: Routledge, 113-8.

Jakobson, R. ([1960] 1988) 'Linguistics and Poetics', in D. Lodge (ed.) Modern Criticism and Theory Harlow: Longman, 32-61.

Johnson, P. (2010) Translation and the Image of the Other: The English Translations of Pablo Neruda's Canto General, PhD thesis, School of Modern Languages, University of Newcastle.

Johnson, R. M. (2016) Reading Barbara Köhler's Niemands Frau as a Radical Poetic Response to Homer's Odyssey, $\mathrm{PhD}$ thesis, German Department, University College London.

Jones, F. R. (2004) 'Ethics, Aesthetics and Décision: Literary Translating in the Wars of the Yugoslav Succession', Meta 49(4): 711-28.

Jones, F. R. (2009) 'Literary Translation', in M. Baker and G. Saldanha (eds) Routledge Encyclopaedia of Translation Studies, 2nd edition, London: Routledge, 152-7.

Jones, F. R. (2010) 'Poetry Translation, Nationalism and the Wars of the Yugoslav Transition', in M. Inghilleri and S.-A. Harding (eds) Translation and Violent Conflict, special issue of The Translator 16(2): 223-53.

Jones, F. R. (2016) 'Partisanship or Loyalty? Seeking Textual Traces of Poetry Translators' Ideologies', Translation and Literature 25: 58-83.

Jones, F. R. and D. Arsenijević (2005) ‘(Re)Constructing Bosnia: Ideologies and Agents in Poetry Translating', in J. House, M. R. Martín Ruano and N. Baumgarten (eds) 
Translation and the Construction of Identity: Iatis Yearbook 2005, Seoul: IATIS, 6895.

Kansu-Yetkiner, N. (2014) 'Words Apart, Worlds Apart: Peritexts from Islamized Translations of World Classics in Children's Literature', Children's Literature in Education 45(4): 340-53.

Kleingeld, P. and E. Brown (2013) Cosmopolitanism, on website Stanford Encyclopedia of Philosophy. Available online: https://plato.stanford.edu/entries/cosmopolitanism/\#2 [last access 27 July 2017].

Lane-Mercier, G. (1997) ‘Translating the Untranslatable: The Translator's Aesthetic, Ideological and Political Responsibility', Target 9(1): 43-68.

Lee, T.-Y. (2010) Translators as Gatekeepers: Gender/Race Issues in Three Taiwan Translations of the Color Purple, PhD thesis, School of Modern Languages, Newcastle University.

Lee, T. K. (2015) 'China as Dystopia: Cultural Imaginings through Translation', Translation Studies 8(3): 251-68.

Lieblein, L. (2004) '"Cette Belle Langue": The "Tradaptation” of Shakespeare in Quebec', in T. Hoenselaars (ed.) Shakespeare and the Language of Translation, London: Thomson Learning, 255-69.

Lobejón Santos, S. (2015) ‘English-Spanish Bilingual Translations of Poetry in Franco’s Spain', in A. Fuertes and E. Torres-Simón (eds) And Translation Changed the World (and the World Changed Translation), Newcastle upon Tyne: Cambridge Scholars, $47-$ 60.

Lovrenović, I., ed. (2002) ‘The Voices of Sarajevo’s Night', tr. M. Lovrenović and R. Hudson, in F. R. Jones and I. Lovrenović (eds) Reconstruction and Deconstruction, special issue of Fourm Bosnae 15(1): 303-12 . 
Lung, R. (2004) 'The Oral Translator's "Visibility": The Chinese Translation of David Copperfield by Lin Shu and Wei Yi', TTR: Traduction, Terminologie, Rédaction 17(2): $161-84$

Määttä, S. K. (2004) 'Dialect and Point of View: The Ideology of Translation in the Sound and the Fury in French', Target 16(2): 319-39.

Mahmutćehajić, R. [1994] (1996) Living Bosnia, tr. S. Beus and F. R. Jones, Ljubljana: Oslobodjenje International.

Matei-Chesnoiu, M. (2006) Shakespeare in the Romanian Cultural Memory, Madison, NJ: Fairleigh Dickinson University Press.

Mihăilă, R. (2005) 'The Politics of Translation: The American Novel in the 19th Century Romanian Territories', British and American Studies / Revista de Studii Britanice și Americane 11: 285-89.

Miłosz, C. (1988) ‘A Poet's Reply', New York Review of Books 35(12). Available online: http://www.nybooks.com/articles/1988/07/21/a-poets-reply [last access 31 August 2017].

Mira, A. (2010) Dubbing, on website Historical Dictionary of Spanish Cinema. Available online: http://spanish_cinema.enacademic.com/70/Dubbing [last access 31 August 2017].

Miščević, N. (2014) Nationalism, on website Stanford Encyclopedia of Philosophy. Available online: http://plato.stanford.edu/entries/nationalism/ [last access 27 July 2017].

Offord, D. C. and V. Rjeoutski (2013) Translation and Propaganda in the Mid-Eighteenth Century: French Versions of Sumarokov's Tragedy Sinav and Truvor, on website History of the French Language in Russia. Available online: 
https://frinru.ilrt.bris.ac.uk/sites/default/files/Sumarokov\%20introduction.pdf [last access 25 August 2017].

Rosenthal, M. (2011) ‘Czesław Miłosz’s Polish School of Poetry in English Translation’, Przektadaniec, 25: 221-8.

Sampson, F. (2001) 'Publishing Poetry in Translation in the UK: The Slovak Experience', Javnost / The Public 11(4): 79-89.

Scottish Poetry Library (2012) William Neill (1922 - 2010), on website Scottish Poetry Library. Available online:

http://www.scottishpoetrylibrary.org.uk/poetry/poets/william-neill [last access 31 August 2017].

Shamma, T. (2005) 'The Exotic Dimension of Foreignizing Strategies', The Translator 11(1): $51-67$.

Simons, H. (2009) Case Study Research in Practice, London: Sage.

Sinibaldi, C. (2011) 'Pinocchio, a Political Puppet: The Fascist Adventures of Collodi's Novel', Italian Studies 66(3): 333-52.

Slapšak, S. (ed.) (1997a) Special issue of Pro Femina 1997.

Slapšak, S. (1997b) 'Women Who Steal Language', in S. Slapšak (ed.), special issue of Pro Femina 1997: 11-8.

Somacarrera, P. (2005) “"How Can You Use Two Languages and Mean What You Say in Both?" On Translating Margaret Atwood's Poetry into Spanish', TTR: Traduction, Terminologie, Rédaction 18(1): 157-81.

Sugars, C. (1996) 'Prochain Épisode, or, Charting Canonical Time', Canadian Review of Comparative Literature / Revue Canadienne de Littérature Comparée 23(4): 1125-43.

Tan, Z. (2015) 'Censorship in Translation: The Case of the People's Republic of China', Neohelicon 42(1): 313-39. 
Toth, A. J. (2015) 'Recent Work in Translation Studies: A Review', Comparative Literature Studies 52(4): 843-52.

Tymoczko, M. (1999) Translation in a Postcolonial Context: Early Irish Literature in English Translation, Manchester: St. Jerome.

Tymoczko, M. (2003) 'Ideology and the Position of the Translator: In What Sense Is a Translator “In Between”?', in M. Calzada Pérez (ed.) Apropos of Ideology: Translation Studies on Ideology - Ideologies in Translation Studies, Manchester: St. Jerome, 181201.

Tymoczko, M. (2014) 'Why Literary Translation Is a Good Model for Translation Theory and Practice', in J. Boase-Beier, A. Fawcett and P. Wilson (eds) Literary Translation: Redrawing the Boundaries, London: Palgrave Macmillan, 11-31.

Venuti, L. (1995) The Translator's Invisibility: A History of Translation, London: Routledge. Venuti, L. (2000) 'Translation, Community, Utopia', in L. Venuti (ed.) The Translation Studies Reader, London: Routledge, 468-88.

Verschueren, J. (2012) Ideology in Language Use. Cambridge: Cambridge University Press.

Weston, A. (2006) 'Sophocles on the South Bank: Tony Harrison Translatee and Translator', in N. Armstrong and F. M. Federici (eds) Translating Voices, Translating Regions, Rome: Aracne, 235-53.

Yin, R. K. (2014) Case Study Research: Design and Methods, 5th edition, London: Sage.

\section{FURTHER READING}

Calzada Pérez, M. (ed.) (2003) Apropos of Ideology: Translation Studies on Ideology Ideologies in Translation Studies, Manchester: St. Jerome.

The Introduction gives an expert overview of translation and ideology, and case studies add useful examples. 
Casanova, P. ([2002] 2010) 'Consecration and Accumulation of Literary Capital: Translation as Unequal Exchange', tr. S. Brownlie, in M. Baker (ed.) Critical Readings in Translation Studies, London: Routledge, 285-303.

An important discussion of literary translation as cultural geopolitics.

Jones, F. R. (2011) Poetry Translating as Expert Action, Amsterdam: John Benjamins. This book sets out a model of poetry translation that includes the sociopolitical. Chapters $2-3$ examine how poetry translating teams operate in the politically-charged situation of Yugoslavia's break-up.

Tymoczko, M. and E. Gentzler (eds) (2002) Translation and Power, Amherst \& Boston, MA: University of Massachusetts Press.

The Introduction gives an expert overview of translation and power, and case studies add useful examples. 